DOI: http://dx.doi.org/10.33846/hn21105

http://heanoti.com/index.php/hn

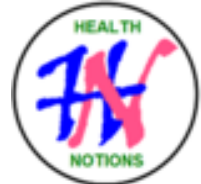

RESEARCH ARTICLE

URL of this article: http://heanoti.com/index.php/hn/article/view/hn21105

\title{
Assessment of Men's Role on Mother Care when Pregnant, Birth and Breastfeeding
}

\author{
Mariana Ngundju Awang ${ }^{1(\mathrm{CA})}$ \\ ${ }^{1(\mathrm{CA})}$ Department of Midwifery, Health Polytechnic of Kupang, Indonesia; ramyakeyken@ gmail.com \\ (Corresponding Author)
}

\begin{abstract}
Background: The maternal mortality rate (MMR) in East Sumba is one of the highest in the province of East Nusa Tenggara (NTT) for the past five years (2011-2015). Maternal mortality in East Sumba District is $76.7 \%$ occurred during childbirth and $23.3 \%$ during pregnancy. The Sumba tribe is based on patriaki culture which prioritizes men as the masters. Male participation is very small, but their control of women in deciding for women to use contraceptives or not very dominant Methods: The type of research used was qualitative research by means of in-depth interviews and FGDs on 20 respondents. Results: Men were very instrumental in helping their wives from becoming pregnant, giving birth and breastfeeding according to cultural figures, customs, husbands and wives. Conclusion: The role of men when pregnant wives prepare themselves as prospective fathers by following the development of pregnancy and supporting the preparation of childbirth, when the wife gives birth to accompany the wife before and during childbirth by giving motivation to face the pain, struggle to give birth to the baby, and when breastfeeding wife Supports the success of breastfeeding, especially exclusive breastfeeding
\end{abstract}

Keywords: men's role; East Sumba culture; traditional figure; religious figure

\section{INTRODUCTION}

\section{Background}

The most occurrence of maternal and neonatal deaths occur during labor, after childbirth, and the first days of infant life continue to occur today. The maternal mortality rate in East Sumba is one of the highest in the province of East Nusa Tenggara (NTT), that of the 14 districts that received AIPMNH intervention in NTT, East Sumba is only one level below the Timor Tengah Selatan District (TTS) in terms of high maternal mortality rates. and child. In 2014 for example, maternal deaths in TTS amounted to 23 followed by East Sumba with 19 deaths. Other districts only ranged from 10 deaths or less. ${ }^{(1),(2),(3)}$ MMR and IMR in East Sumba Regency are still relatively high based on the annual report of the East Sumba District Health Office for the past five years (2011-2015). Results of the study in 2016 Maternal deaths in East Sumba District 76.7 percent occurred during childbirth and 23.3 percent during pregnancy. ${ }^{(4)}$ Therefore, to reduce the Maternal and Newborn Mortality Rate, new efforts and innovations are needed, can not be done in ordinary ways and need to study more in other causes so that the MMR and IMR can be gradually lowered.

Culture is an inseparable part of the human self so that many people tend to assume that it is genetically inherited, cultural aspects also determine human social behavior because culture is a pattern of whole and complex, abstract and broad. Culture is a belief that is believed to be hereditary, one of which is gender differences, which has given rise to differences in roles, responsibilities, rights and functions and activities of men and women in society. ${ }^{(5)}$ Culture driven by patriarchal culture interprets the biological differences between men and women as indicators of appropriateness in behavior which ultimately leads to restrictions on rights, access, participation, control and enjoy the benefits of resources and information. Finally, the demands of roles, duties, positions and obligations that are appropriate for men or women and which are inappropriate for men or women vary greatly from one community to another. ${ }^{(6)}$

There are some people who are very rigid limiting the role that is appropriate to be done by both men and women, for example a taboo for a man to enter the kitchen or carry his child in public and taboo for a woman to 
often leave the house to work, there are also some a flexible community that allows men and women to carry out daily activities, for example women are allowed to work as construction laborers to climb to the roof of the house or climb coconut trees, while men mostly save chickens to gamble. The hierarchy of space and spatial planning in the Sumba traditional house is very clear with a pattern that separates areas of men and women or the division of space separated by male and female (male-female) and formal - informal spaces. The right side of the house is a function that is more sacred while the left is used for daily activities and domestic needs in the household. The right side is considered as a male area, the left area is considered a female area. The Sumba tribe adheres to a patrilineal kinship pattern, where the father or grandfather will become the identity of the Sumba tribe. ${ }^{(7)}$

The Sumba tribe is based on patriaki culture which prioritizes men as the masters and women as the masters. This very powerful paternalistic system is demonstrated by the existence of a system of division of inheritance of property, that is, boys receive directly from their grandfather without having to go through the father of the boy. The position of women is very weak in sumba ethnic culture which is reflected that girls do not need to be schooled as high - if there is a son in a family, the position of women is weak in deliberation or decision making, not even involved. the gender roles of women as nurses, caregivers and educators are natural and are considered inferior to male gender roles, giving rise to injustice, discrimination and oppression of women, where they are caused by a value system that is given cultural significance. ${ }^{(8)}$

The Sumba tribe adheres to a patrilineal kinship pattern. The kinship pattern in which their father or grandfather will become the identity of the Sumba people. The Sumba tribe is a tribe that is very open with changes and a system of governance. This has a positive and negative impact on the culture of the Sumba tribe. ${ }^{(9),(10)}$

Male participation is very small, but their control of women in deciding for women to use contraceptives or not very dominant. The community still places female objects in sexual and reproductive problems, because those who are pregnant and give birth to women must take part in contraception so that they are not pregnant, take care of their children and take care of household activities. Based on the above, the researcher wants to study the role of men about maternal care during pregnancy, childbirth and breastfeeding in the culture of East Sumba. ${ }^{(11)}$

\section{Purpose}

General Purpose: Assessing the role of men about maternal care during pregnancy, childbirth and breastfeeding in East Sumba culture.

\section{Special Purpose:}

1) Assessing the role of East Sumba men in the care of pregnant, childbirth and breastfeeding mothers

2) Assessing East Sumba Culture about the care of pregnant women, childbirth and breastfeeding

3) Assessing the role of men about maternal care during pregnancy, childbirth and breastfeeding in East Sumba culture

\section{METHODS}

The type of research used was phenomenological research with a qualitative design. Researchers collect data regarding concepts, opinions, standpoints, attitudes, judgments and giving meaning to situations or experiences in life, with the aim of finding or discovering the meaning of essential or fundamental things from life experiences through in-depth interviews (independent interview) against respondents.

The population and sample in this study were (1) Men with married status, length of marriage> 10 years, first marriage, children $>2$ people, both living in the city and in the countryside (2). Men of Customary Leaders and Religious figures who live in cities and rural areas. Sample selection was done by purposive sampling in the sub-district or village which has the highest maternal and infant mortality rates in the last 2 years.

Data collection in this study was carried out by in-depth interviews and FGD using the Interview Guidelines compiled by the researchers themselves towards respondents, men and traditional leaders and religious leaders who met the criteria. Data collection was done to find answers to questions or problems in this study.

Data analysis was the process of systematically searching and compiling data obtained from interviews, field notes and documentation, by organizing data into categories, describing it into units, synthesizing, composing into patterns, choosing which ones are important and what will be learned, and make conclusions so that it is easily understood by yourself and others. Data is processed manually by means of qualitative data analysis, namely: Data Reduction and Categorization: According to Miles, data reduction is an electoral process, focusing on simplifying, abstracting, and transforming rough data that arises from field data. It is necessary to do data reduction because in general, qualitative data is very large, especially from interviews and observation. After doing data reduction and must proceed to data categorization. Data display is an analysis of designing a 
row and column of a metric for qualitative data and determining the type and form of data entered into the metrics boxes. The data can be displayed in narrative form, charts, flow charts, and others. Withdrawal of conclusions: After the data processing phase above, the researcher will make conclusions include the involvement of men either as husbands or traditional leaders or religious figures actively in helping the mother or woman or his wife since pregnancy, childbirth and breastfeeding and the beliefs adopted for generations by East Sumba community in terms of maternal care during pregnancy, childbirth and breastfeeding

\section{RESULTS}

\section{Results of Interview and FGD}

1. Topic: Men involvement either as husband or traditional leader or religious figure actively in helping mother or woman or wife since pregnancy, childbirth and breastfeeding

Opinion of custom leaders:

"Jaka patu wula naka bana woru ihi, hina pa una hi pandau acara, siap manu patu ngiu kata hamayang kana mandung dangu kana malundung taka hina dedi".tuna dumbu jaka walu bo wula naka hamayang wuanya pangangu da apu atau boku tamu na, hala ka nu hi manahuya kana ngangu nama woru ihi dangu nyuta mbulu daba da". His means that if the mother or wife is pregnant / pregnant in the new 4 months of pregnancy, the event will be held as a form of concern for the husband by preparing 4 chickens to be cut in the form of highprotein animal-based foods such as chicken and chicken eggs to strengthen the fetus in the womb to give birth safely, age 8 months to approach childbirth is also held a show of love, with the intention to be able to give birth safely mother and fetus so that the chicken cutting ceremony is held to be given food with the same menu at the age of 4 months to his wife and also for ancestral spirits for the Marapu.

"Hamang ke nyaka na mbuhangu pa lua la posyandu atau uma hidu papareha biasa pa kariangu mayaka una jaka da ningu ngia palua hau da tau mini/da le da" jaka dia laku meha mana yaka papareha". it means that during a pregnancy check, the husband can deliver if there is no other activity, if there are other activities, the wife goes away by relatives or goes alone.

"Hau ma yai jaka na mbuhangu pahabuala la uma hidu atau Puskesmas da Le atau na tau mini harus lua ma ka una paka rianya sampai taka la uma hidu, dangu patiang, jaga ya taka hina mangailar, ngandi ha na karia na untuk pa tani nya lama uma, sekaligus ngandi ha na katari marihak pa mbaha ha la uma, laku pa ma nahu wai, pangangu baru ngandi beli la uma hidu ka na ngangu na ma hina mangailar lu". So according to Customary Leaders, when giving birth a husband is obliged to deliver because the wife cannot go alone in a state of illness, must be accompanied and waited until after giving birth, take home the placenta, dirty clothes to the house to plant and wash, then cook rice, water to then bring to the hospital for iistri or the mother who has just given birth to food. After leaving the hospital, go home until the wife's house is given food with a menu of rice, vegetables, chicken meat and chicken liver, for 1 week. after eating a break, take a hot shower such as a hobby on the body except the pubic area if there is a stitch and then sleep near the fireplace or stove whose fire is lit with a medium heat level so that the mother and baby can warm up. able and high caste or Maramba in the hierarchy of the people of East Sumba can do Hamayang or prayer for thanksgiving, especially if they have boys who they have been waiting for for a long time by cutting horses, cows, pigs and chickens and inviting many people because of the Sumba Community The East adheres to the Patrilineal ideology or the lineage of the father / grandfather as the descendants of descendants.

Opinion of community leaders:

If there are mothers who are pregnant, the husband needs to help accompany them when checking to the health center or hospital if the husband does not go to the plantation or go to traditional activities or have family business. Check for pregnancy if necessary and do not need to check continuously unless the wife has a problem or has a complaint. "Jaka da woru ihi na papaha da maka harus ma ka una karia ja la uma hidu jaka da da lua la marama wuaka atau pa kikungu hori luri atau hori meti',.

When I want to give birth to a husband help find the first helper in the past, we looked for a birth attendant, if now it is difficult to find a birth attendant, have to find a midwife, we contact to be able to come to help deliver labor at home, after the regulation that all must give birth at the health center or home sick, the midwife will no longer come to help at home so sometimes because it is normal for us to help deliver at home or to the Community Health Center or hospital if we are afraid of giving birth at home.

"Tuna numbu jaka mbuhangu pahabuala atau pamangailar da Le maka una dama himbu tau untuk bantu ya na papaha/kuru uma, jaka amangu ma dukun a ma ningu taka jaka nahu harus himbu bidan atau dotir maka una, ba aturan na tuna tunu, jaka ndia wada da bidan harus mai la uma hidu atau puskesmas". 
Because in our opinion, women giving birth are normal and natural things that don't need to be helped too much. But lately different times so women need to give birth in the help of midwives or doctors at health centers or hospitals. Because many are also not helped by the mother because of bleeding or left behind and the baby because of drinking amniotic fluid and unable to breathe. If in the hospital there is already a tool for breathing and infusion or medicine for mothers so that they can survive both mother and baby.

When breastfeeding mothers must eat lots of rice and vegetables and meat if there is to increase breast milk production and the health of breastfeeding mothers to recover quickly and be able to do homework again properly, even though after childbirth women must and still take care of themselves and their children or husbands in the house stairs.

Husband's opinion:

As long as the wife is pregnant or pregnant, they will try to accompany, escort or accompany if they check with the community health center and hospital if they have no other important work. If you can't, the wife usually goes alone because it's normal and just walk to be healthy or ojek if you have money. The food that the wife eats during pregnancy remains the same as the period of not getting pregnant, only I see them eating more and more. The bidan said that healthy womb children and pregnant mothers were healthy and strong during childbirth because they needed energy. Other activities are carried on by the wife even though she is pregnant like, cooking, washing, lifting water, lifting firewood, brooming the house and even pulling the grass or cleaning the garden because pregnancy is normal and natural. Keep serving your husband and children like before getting pregnant because the wife must obey her husband as the people of East Sumba are, except if the wife is ill, unable to work anymore, she does not want her husband to work, if their nobles or marimba are servants who replace, if the villagers or Ata then usually have to work to replace the wife.

When we gave birth if in the past there were still traditional birth attendants, we used a traditional healer, if we don't have it now, then we call the midwife to come and give birth at home, but now the midwife doesn't want to come again because there are new rules that prohibit giving birth at home. to the hospital or community health center already because my wife had bleeding when she gave birth to a third child, almost died quickly and became a baby. I then went to the midwife. I accompanied her until I gave birth, brought home ariani for planting, and dirty clothes for I wash if no other family helps and cooks food, hot water to bring to the hospital or health center so that the wife can eat, drink hot water to recover quickly.

After returning home, during the breastfeeding period, the wife must eat a lot, drink plenty and have adequate rest so that breast milk is sufficient for the baby, so the baby does not cry but can sleep soundly and healthy, besides the wife must eat fried corn and fried beans to add the amount of ASI, the husband will help if the wife is not able to do the work herself during breastfeeding, but if she is still able to breastfeed his wife still works alone to serve her husband and children and the whole household.

Wife's opinion:

"Ai jaka da pi gama ba wori ihi maya, ya biasa ba dumu, da lalu ningu rihi na, pa daingu ba bama rama pangangu, taku wai, himbu ai epi, tungu uhu wei, manu, hapi, jara, baha katari, kanjiaku. Paling paarangu da tuama patu wula ka hi da hamayang, wuaja uhu da apu-boku tamu, rupu manu 4 ngiu, nyuma kadi ma manahu pangangu (tolu manu, eti dangu kawanggal na), banahu mangilu ya untuk hamayang, nama rihi baru ma ngangu nyuma tau wori ihi. Memang da wua parihi magama nyuma kai ngangu padangu, kana mandungu na ihi kambu dan kana sehat na ana kiada taka hina dedi',

That is, since husbands know that they are pregnant with children or are not too privileged, meaning they continue to work as usual in doing household chores such as cooking, lifting water, lifting firewood, feeding animals, up to 4 months of pregnancy which they think is the content It has been strong enough and can be maintained as a fetus so prayer or Hamayang is held by cutting 2-4 chickens, after chicken meat is cooked (we are also working wives), after cooking, first, the liver, meat and bile are taken first to be given to ancestors were given to ancestral gods (for the marapu) in order to maintain the health and safety of the fetus and mother during pregnancy, after which they ate where the wife was given a large portion of meat such as liver and meat so that the fetus was healthy and the mother was strong. For pregnant women who are already religious, they are no longer like that and there are no chicken slaughter ceremonies but also worship activities as usual, namely the church, household worship etc.

"Nyiama yai jaka taka la wulang pa walu wamaka bama wori ihi, hili hamayang mai, wuaja uhu da boku, apu kada namu, ai, jaga kama taka hi ma habuala dangu hamu, hawuala ina dan ana rara".beli kan la uma hi hamayang mai peri hanggobung, jadi rupu manu wuaja uhu da boku, apu tamu sekaligus maka du ba tuna tamu na ana rara nama hina dedi (hamayang ba kadipu ya puhu na hi tunya tamu na) ba tuna nupa duma nyuma tau marapu, jaka tama la ka gereja una dapa hamayang tuna tuapa.halapa mangailar rama biasa ma, kecuali nu jaka 
masih katiu mayapa, na tau mini/le harus rama ma ka una, atau jaka ningu ana kena marama jiaduya ka hina rama",

His means that Hamayang is also carried out at 8 months of pregnancy as a preparation for childbirth, to be safe in the delivery process for mothers and babies. After giving birth to go home and do the work as usual, unless the wife is still feeling sick or not strong then the husband will help with household chores such as cooking, washing, preparing bath water for his wife and baby or taking care of the wife to accompany and accompany to the Community health center or hospital or doctor practice for treatment. The husband will also accompany the mother and baby to the Posyandu if there are no other activities done. Unless there are children working at home who can help.

"Da Le ma mai dama paingat gama kai pahuhu pahamu ja da ana rara, humbug da hi manu, talanga na beni ma, jaka na hi paduang ka da ana rara, nggara ulamu kahia?da bisa mai pa lunggu ana rara, pama huru ha, pahilu ja jaka da hambeli atau da rumba, pahuhu ana rara taka dambu dau, jaka amangu, 3 wula ada pa bada wuaja ga pangangu, jaka nahu dia apa, nomu wula dapa hina hi wuaja bubur na ana rara wada na bidan, dotir la uma hidu"

This means that the husband will usually remind the wife to breastfeed her baby especially if she cries continuously, the husband will be angry, pay attention to the wife's food, help carry the baby and put him to sleep, change the wet or dirty diaper if the wife is cooking. Husbands usually tell their wives to continue breastfeeding until the age of 2 years. Indeed, in the past, babies were given food when they were 2-3 months old, but after we knew the information from the midwife and the doctor was not allowed, then there was no food other than ASI until the age of 6 months.

2. Topic: Beliefs passed down through generations by the East Sumba community in terms of maternal care during pregnancy, childbirth and breastfeeding:

If a mother is pregnant or pregnant, the husband or men must ascertain whether they are pregnant with their husbands or with other people or because of an affair, if indeed the child in his birth is the baby's heart then two male and female chickens, rice, sugar coffee are prepared tea leaves, betel nut and lime to do a thanksgiving in the form of thanksgiving so that the pregnancy can last well until even months and give birth safely. the dream is done by Custom leader or wunang who used to lead prayer and clever luluk (speaking indigenous language) by cutting the chicken, taking liver and meat content to be given to pregnant women to eat as a sign of concern for men for maternal safety during pregnancy and during childbirth, such dreams are performed twice during pregnancy, namely at 4 months and 8 months of pregnancy or approaching giving birth. besides the age of pregnancy above there is no custom or belief so keep eating, drinking as usual, working, resting or doing household activities as usual by a wife without the help of a husband or husband only helps if the wife is sick. Stay accompanied to the hospital or health center or if the culture used to call a traditional birth attendant to order and give a concoction of medicine to drink as an ingredient booster or also to take a bath so that the body is healthier and stronger

During childbirth there were also gifts to thank mothers and babies who had been born safely and healthy by cutting chickens which were also given to mothers who had just given birth to be eaten as a substitute for blood that had come out and returned their energy after struggling to give birth to their babies. many and babies are not fussy because breast milk does not exist or is lacking.

Such ceremonies above are only carried out by East Sumba people who still adhere to the Marapu / belief stream, for those who have Christianity and other religions, they are carried out at any time by husband and wife while the thanksgiving is only at the baptism of children or sidi, new welcome or circumcision. ceremonial activities. The following traditional ceremonies will be held after a large child or boy and girl want to propose or get married, the male role is to talk about customs in the form of animals (cows, horses, goats, pigs, buffaloes) and mamuli, gold or silver luluamahu, also cloth in the form of hinggi and lawu humba and the money used during the adat process, tap the door, enter the request and the wedding ceremony in the church and civil records.

\section{DISCUSSION}

Cultural health is the study of the influence of cultural elements against penghayatan community about sickness and health. ${ }^{(12)}$ According to the Foster and Anderson $\left.{ }^{(13)}\right)$, the culture of health examines health issues and disease from two different Polar polar biology (i.e., growth and human development, the role of disease in human evolution and paleopathology or the study of ancient diseases) and socio-cultural pole (traditional medical system or etnomedisin, the officer issues a health worker, behaviour of pain, the relationship between patient, doctor and dynamics of business introduced the Ministry of health to people's traditional Cultural Health), so is the discipline that gives attention to the aspects of the biology and culture of human behavior, 
especially on ways of interaction between the two throughout the history of human life, that influence health and disease in humans.

The results of the interviews and FGD by topic/theme of the involvement of men - a good man as husband or religious figures or custom personalities actively in helping mothers or sisters or his wife since the pregnant, giving birth and breastfeeding found that if the mother or wife already contains/is pregnant at the age of 4 months of pregnancy the new prayer event will be held as a form of husband's attention by setting up a chicken's tail for 4 in pieces in the form of feeding a high protein derived from animal meat such as chicken, eggs and chicken to strengthen the fetus in the womb to give birth safely, age 8 months want to approach childbirth also held prayer events in order to be able to safely give birth to mother and fetus so that held the ceremony for the chicken given the same menu with food at a time when the age of 4 months to his wife and also for deceased ancestors for adhering Marapu beliefs

It is the custom prevailing in East Sumba, which complies with the definition of custom is a rule which should not be constrained by a society in which the legislation claiming that unwritten but binding, in all its forms traditional art Sumba will we see or we feel the breath of life of the local customs, both indigenous life that ever existed in the past, as well as customs still lived a community of today. Customs shared by the tribe of Sumba. ${ }^{(9,14)}$. It is also in accordance with what was said about culture is everything that individuals from the community, including the beliefs, customs, norms, eating habits, artistic expertise obtained not from his creativity itself but rather is a legacy of the past that is obtained through formal or informal education. In addition, while pregnant and gave birth to a woman should still pay attention to the food consumption in order for the baby he was born healthy and fulfilled conditions in all kinds of nutrients to grow flower infant. ${ }^{(15)}$

According to the Customary character of East Sumba, when his wife gave birth to a husband willing to take mandatory because his wife could not go alone in his illness, must be accompanied and in tunggui to finish giving birth, bringing home ari-ari, dirty clothes home to in the planting and washed, then cook the rice, water and then brought to the hospital in order to iistri or new mothers give birth to eat. Once out of the hospital, going home to his wife at home is given food with rice, vegetables, chicken meat and chicken liver, for 1 week. After having a break, then showering with hot water as it tatobi the body except the pubic area if there are stitches and then sleeping near a fireplace or a furnace fire ignited with a level of moderate heat so that mother and baby can be warm. No Sembayangan event is done except for the circle that is capable and high-caste or Maramba in the hierarchy of society East sumba can do Hamayang or prayer for Thanksgiving, especially if it gets a boy - boy who had long been their look forward to that is by cutting the animals horses, cows, pigs and chickens and also invited a lot of people because of East Sumba Communities embraced the doctrine of a Patrilineal people or bloodlines father/Grandfather as successor

This is in accordance with that in East sumba cultural observers say that is Hamayang or sembayang or ceremony of Thanksgiving will normally be conducted in accordance with ability and caste/levels in East sumba, for the King usually if getting boys Moreover, as long as it gave birth to the girls then mandatory for a big party with cut animals such as Horses, cows and pigs to celebrate happiness because getting a boy - boy who became the successor of the descendants because the tribe embraced a doctrine of East Sumba Patrilineal people, continued the father's Surname/Father in his family. So it's not uncommon to many wives have to bear a child 8-10 person just because it hasn't gotten a boy - men. Thankful for today because it required the Government to KB so no longer the wife got pregnant and gave birth to a lot of people are just 2-4 pretty much otherwise yeah boy can later be son-in-law, grandson of a new forward Clan Opa or Grandpa so not lost. ${ }^{(14)}$.

Patriarchy can also be explained where the State of a society that puts a position and the position of men is higher than for women in all aspects of social life, culture and the economy. Socio-cultural conditions that allow the females are in the sub ordination, leading to decision-making in KB is dominated by men. ${ }^{(16)}$ Is a patrilineal people related by blood according to the lines of Mr. radiate from a father of origin; only this is the rope that connects the posterity. So that way everyone who truly berbibit on Mr. origin [a patrilineal people (family or clan ("geslacht")] or according to tradition is considered a derivative (clan), is calculated to a fellowship of the law (for example: on the Batak, Nias, Indonesia, and so on). ${ }^{(17)}$

Typical regional trust Marapu, the ancestral half, demi-gods, still very alive amongst the people of Sumba. Marapu became the basis for a wide variety of philosophical expression of Sumba culture ranging from the customary ceremonies, the synagogue (umaratu) custom homes and design Ordinance bangunnya, variety variety of ornamental carvings and textiles up to manufacture the device clothing fabrics such as hinggi and lau as well as weapons and jewelry supplies. ${ }^{(18)}$ In East Sumba social strata among the nobility (maramba), religious leaders (kabisu) and commoners (ata) is still valid, although not past and future who whet obviously also not also seem more for real on the make-up and the clothes. ${ }^{(9),(18)}$ The culture's very closely related to the community, ${ }^{(19)}$ suggests that everything that exists in a society is determined by the culture that is owned by the community itself.

The Opinion of Community Leaders; If there is a mother who got pregnant then the husband need help accompany check into a Clinic or hospital if husband not to garden or go follow the customary activities or there is a family affair. Check out pregnant if necessary and do not need to check continuously unless the wife there is 
a problem or complaint, childbirth also look for helpers such as herbalists and midwives, accompanied to the hospital, waiting to give birth to and bring home the ari-ari for planted and dirty clothes to be washed and returned to the hospital to bring wife food, hot water and clean clothes and money for the needs of the hospital. postpartum women are already fixed and have to take care of yourself and the child or husband in the household.

This is in accordance with what was said that domestic Tasks is considered, the working wives, husbands rarely involved taking care of the household and the children intensively ${ }^{(20)}$. Since centuries ago, particularly the role of women in traditional society is indeed always synonymous with household chores. Its activity is not far from the kitchen and beds. Like cooking, serving food, set up the House, taking care of children and mempersolek (dress or attire) myself to the husband, so there is no time for his wife out of the House following the investigations or other social event. There is no term men more than women or vice versa women more than men except in terms of earning a living. Everything is fair in accordance with his nature respectively, they have rights and obligations of each, have become the nature of women to give birth so that women as reproductive machines (pregnant, giving birth, and breastfeeding) must be able to take care of, educate, raising his children and also taking care of her husband in a society, where traditionally ${ }^{(21)}$. It is also in accordance with the traditions of the local community has had people that are budayawi assigned to handle childbirth i.e. baby shaman (quack litter, paraji or other terms in accordance with the environment and culture). He not only handled the birth process, but the remote handles the day before and also after. Young pregnant at the time, joined a newborn baby candidates celebrate the handle, i.e. a slametan neloni ( $3-4$ months of pregnancy) and mitoni (pregnancy $7-8$ months). After childbirth also handles up to selapan old baby (40 days). Baby shaman has an important role for the survival of the family and Mashallah rakat, he was given a respectable status. When involved in the various activities of the ritual on the pregnancy, she received me tumpeng or whatever as a form of thanks and respect are peng budayawi, as experienced by Mbah Shaman S (55 years) in Madiun ${ }^{(22)}$.

Husbands say that, as long as wives contain or become pregnant, they will try to accompany, accompany or accompany them if they check with the Hospital and Community health centers if they have no other important work. Other activities are carried on by the wife even though she is pregnant like, cooking, washing, lifting water, lifting firewood, brooming the house and even pulling the grass or cleaning the garden because pregnancy is normal and natural. Keep serving your husband and children like before getting pregnant because the wife must obey her husband as the people of East Sumba are, except if the wife is ill, unable to work anymore, she does not want her husband to work, if their nobles or marimba are servants who replace, if the villagers or Ata then usually have to work to replace the wife. When I want to give birth, I take it to a midwife, I accompany it until I give birth, bring home ariani for planting, and dirty clothes for me to wash if no other family helps and cooks food, hot water to bring to the hospital or community health center so that the wife can eat, drink hot water to recover quickly. This is consistent with the statement that childbirth is the toughest and most beautiful period in a woman and will feel beautiful and can fight the pain that is felt if a husband is beside us, who always accompany and provide support. Unlike the past which did not allow husbands to enter the delivery room. Currently the hospital and doctors have allowed it. It has been realized that with the husband beside the wife's birth, it will be very helpful. Husbands can provide support beyond others. The relationship between parents and children will also feel thicker ${ }^{(23)}$. Childbirth is a fairly heavy period for mothers, where the birth process is like a mother's life and death stakes, especially in primiparous mothers, where they do not have the experience of giving birth. Anxiety can arise due to concerns about a safe birth process for himself and his baby ${ }^{(24)}$.

Social support is very important to be given to mothers in labor. The support provided can be done by husband, family, close friends, or health professionals. One of the principles of care for mothers is to include their husbands and families during labor and delivery ${ }^{(25)}$. The Government of Indonesia through the Ministry of Health campaigned for the program "Suami Siaga" in 1999 - 2000 in order to increase the role of husbands in the "Making Pregnancy Safer" program. The aim of this program is to increase the knowledge, involvement and participation of husbands in maternal and newborn health services ${ }^{(26)}$. Continuous support from a childbirth companion to the mother during labor and childbirth can facilitate labor and delivery, provide a sense of comfort, enthusiasm, encourage the mother and increase maternal self-confidence, and reduce the need for medical action ${ }^{(27)}$. The presence of a husband or close relative will bring calm and keep the mother away from stress and anxiety that can complicate the birth and childbirth process, the presence of the husband will bring a positive psychological impact, and also have a positive impact on the physical readiness of the mother ${ }^{(28)}$.

One of the roles performed between husband and wife in the household is the role of childcare. This is related to family affective roles mentioned by Epstein, Bishop, and Baldwin in ${ }^{(29)}$, that family affective roles relate to one of the family's functions for care and provide emotional support (providing nurturance and emotional support) So this study focuses on husband and wife relationships in caring for their children. The presence of a husband on the side of his wife who is ready to give birth certainly brings peace to his wife. Fear, panic, and tension with the pain during childbirth seem to disappear Calmness and happiness that comes from your husband's attention and affection can also increase blood circulation in the mother's body so that it is 
beneficial to increase breast milk production. Another form of husband's attention and affection to his wife during pregnancy is to give a touch of affection and kiss the wife's stomach, provide food full of nutrition, help find information about pregnancy, remind the wife to take supplements and vitamins from a doctor, take over most domestic work, Gently massage the wife, invite the wife to exercise lightly, send the wife to the doctor, motivate the wife to take part in the prenatal class, accompany the wife during labor, provide labor costs, provide equipment and baby equipment, discuss the name of the prospective baby. The role of the husband in pregnancy is very influential on the health of his wife and fetus ${ }^{(24),(30)}$. The role of husband to wife during breastfeeding Always provide support. A husband must always provide support to his wife while she is breastfeeding her baby, because the process of breastfeeding is not an easy job. Try to do attention starting from a small thing, for example by bringing a glass of water or maybe an extra pillow that can be needed support. Husbands can also help carry a baby who is about to suckle, then help make the baby belch afterwards. This psychological factor will make breastfeeding mothers who are supported tend to breastfeed longer, than those who lack support from their husbands ${ }^{(31),(32)}$.

\section{CONCLUSION}

Men play a good role in helping mothers or wives during pregnancy, childbirth and breastfeeding, namely:The role of men when pregnant wives prepare themselves as prospective fathers by following the development of the wife's pregnancy and supporting the preparation for childbirth. The role of men when the wife gives birth to accompany the wife before and during childbirth by giving motivation to face the pain and struggle to give birth to the baby and The role of men when breastfeeding wife Supports the success of breastfeeding, especially exclusive breastfeeding.

\section{REFERENCES}

1. AIPMNH_Prop NTT. AIPMNH Partnership Bulletin. Edition of July 2013.

2. NTT Provincial Health Office. NTT MCH Revolution: All Pregnant Women Giving Birth in Adequate Health Facilities. Kupang: NTT Provincial Health Office; 2013.

3. Anonymous. 5 Provinces contributed the highest maternal and child mortality rates. 2016.

4. Awang MN. Study of Maternal Mortality Based on Frequency of ANC, High Risk Category and Reference to High Risk Cases in East Sumba Regency in 2011 - 2015. 2016.

5. Melovie NO. Definition of roles, status, norm values and culture, culture. Scientific Writing, 2010.

6. Soekanto S. An Introduction to Sociology. Jakarta: PT Raja Grafindo Persada Publisher; 2010.

7. Kapita Oe H. Sumba and Customs Society. Jakarta: BPK, Gunung Mulia; 1976.

8. Petra University. NTT Traditional House of West Sumba Tribe. Research Report. Petra University; 2012.

9. Wellem FD, Gospel, Marapu. Jakarta: BPK Gunung Mulia 2004.

10. Widianto B et al. Cultural Perspective: Collection of Koentjaraningrat's Posts. Jakarta: Rajawali Press; 2009.

11. Puspitawati H. Cultural Views in Indonesia about Gender and Women's Position. 2016.

12. Uciha Ithaci. Influence of Community Social Culture on Health. 2012.

13. Idrus. Feminist Anthropology, Ethnography, Gender Relations and Cultural Relativism in Indonesia. Makassar: Hasannudin University; 2006.

14. Bushar Muhammad. Principles of Customary Law: (An Introduction). Jakarta; 2003.

15. Woha UP. Government History on Sumba Island. Kupang: Undana Press; 2008.

16. Corprius Tarawacu. Influencing marital customs towards the welfare of the people of Sumba Timur. Waingapu, East Sumba; 2015

17. NTT Province. Initiative Policy Update on Public Health Direction \& Policy Strategy for Reducing MMR, IMR \& UFMR. Kupang: NTT Province; 2010.

18. MoH-RI. Guidelines for health services for low birth weight babies (LBW) with kangaroo method care in hospitals and their networks. 2009.

19. Ariesta, Marcheilla. Role of Culture in Society [Internet]. 2011 [cited 2017 Apr 20]. Available from: http://cheillachei.blogspot.com

20. Arikunto S. Research Procedure A Practice Approach. Jakarta: Rineka Cipta; 2006.

21. Abdiana. Determination of Infant Death in the City of Payakumbuh. Andalas Public Health Journal. 2015;9(2):88-92.

22. Paramita P, Sulastri D. Introduction to Customary Law. Bandung: Pustaka setia; 2015.

23. Sugiyono. Understanding Qualitative Research: Bandung: Alfabeta; 2014.

24. West Manggarai, East Nusa Tenggara Province. Maternal and Child Health Determinants in West Manggarai District East Nusa Tenggara Province. Health System Research Bulletin. 2014;17(3):249-256. 
25. Nurrizka RH, Saputra W. Direction and Policy Strategy for Reducing Maternal Mortality Rate (MMR), Infant Mortality Rate (IMR) and Under-Five Mortality Rate (AKABA) in Indonesia. Directions and Strategies for Reducing Maternal Mortality. 2013:1-19.

26. MoH-RI. Pocket Book of Essential Neonatal Health Services. Jakarta: Moh_RI; 2010.

27. Anasari T. Itroduction Maternal Mortality Rate (MMR) is one indicator of women's health status. 2013:26-34.

28. Ministry of Health of the Republic of Indonesia. Assessment of K I and K IV. Jakarta: MoH-RI; 2004.

29. Ministry of Health of the Republic of Indonesia. Pregnancy Care (ANC). Jakarta: MoH-RI; 2007.

30. Ministry of Health of the Republic of Indonesia. Antenatal Service Guide. Jakarta: Jakarta: MoH-RI; 2008.

31. Ministry of Health of the Republic of Indonesia. Guidelines for Antenatal Services at the Basic Services Level. Jakarta: MoH-RI; 2003.

32. Bobak IM, Lowdermilk DL, Jensen MD, Perry SE. Maternity Nursing Books. Edition 4. Interpreting: Maria AW, Peter I.N. Jakarta: EGC; 2005. 